\title{
Hydrogen Supplied Wireless Charging System for Electric Vehicles
}

\author{
N. Campagna, IEEE Student Member, A. O. Di Tommaso, V. Castiglia, F. Pellitteri, R. Miceli, IEEE Member, and \\ G. Schettino
}

Department of Engineering, University of Palermo

Viale delle Scienze, Building nr. 9, 90128 - Palermo, Italy

Email: nicola.campagna@unipa.it

\begin{abstract}
The aim of this work is the experimental characterization of a Wireless Charging System based on IPT (Inductive Power Transfer) supplied by a PEMFC (Proton Exchange Membrane Fuel Cell) in order to verify the possibility of its installation in not electrified areas. A hydrogen-based supply system is designed and assembled with the purpose of having an EV (electrical vehicle) charging station not connected to the main power grid. An efficiency analysis of the wireless transmission system is carried out taking into account external parameters such as distance and misalignment between the transmitter coil and the receiver coil, verifying the integration potentialities of both IPT and fuel cell for the automotive field.
\end{abstract} Cells.

Keywords-IPT, Wireless Power Transfer, PEMFC, Fuel

\section{INTRODUCTION}

Urban mobility is changing and both public and private transportation is going to be closed to the internal combustion vehicles and more opened to the eco-friendly ones, most of all with electric supply. One of the great challenges for the development of the electric vehicles (EV) is the storage of energy. As a matter of fact, most of the research is focused on new technologies that allow EVs being more attractive. In order to increase the number of EVs and their massive utilization, infrastructural works are required and it is due first of all to the lack of charging stations. For this reason, in order to decrease the so-called range anxiety, that is one of the causes of the slow development of the EVs, new technologies must be implemented. The IPT systems can be introduced as a good solution. They represent an innovative approach for the EV battery charging, due to the possibility of wireless operations.

In fact, IPT systems bring benefits not only in terms of comfort, but also in terms of safety. In [1] an overview of the main IPT technologies of EVs is given. Different issues and technical limits based on human safety implications are discussed in [2] and several power efficiency optimization methods for different fields of application are proposed in [323]. In particular, a specific focus on the effects of misalignment and distance on the efficiency is presented in [24].

The only usage of eco-friendly vehicles is not sufficient enough to reduce $\mathrm{CO}_{2}$ emissions and pollution in general. As a matter of fact, although a correct use of energy is assuming more importance, a green generation has not to be neglected.
Wind-turbines and photovoltaic are nowadays the principal technologies in the field of generation, but technologies such as that of hydrogen are equally valid.

Fuel cells are the base of this technology. They are electrochemical devices able to dispense current like a traditional battery, but external reagents are provided to the systems, in particular hydrogen and oxygen. In [25] the generalities and the working principles of the fuel cells are presented. The main characteristics of the different types of fuel cell are described in [26-28] and in [29] a focus on their applications is provided.

Even though fuel cells are one of the best solutions to generate electric energy from renewable sources, they have several technical limits that cannot allow them to be used directly EVs. One of these is their slow response time that does not pair well with the dynamics of the EVs without high performance power converters. Another one is related to the safety because of the presence of massive quantities of hydrogen on board. For this reason, they can be used for residential applications or in general for the generation of electric energy in low dynamic systems. In this paper, a low power prototype of a hydrogen supplied WCS is presented. It is composed by a fuel cell whose purpose is the supply of a wireless charging system based on IPT. The whole system can be used in not electrified areas such as rural areas or car garages. The hydrogen can be also generated locally thanks to an electrolyser supplied by a low photovoltaic panel.

\section{SUPPLY SYSTEM DESCRIPTION}

In this paragraph the hydrogen-based supply system is described.

\section{A. Electric energy generation by hydrogen}

Fuel Cell is composed by two electrodes where a redox reaction between fuel and combustive happens. An electrolyte is placed between the two electrodes [30]. An external electric circuit allows the flow of the electrons produced by the redox reaction from an electrode to the other [31]. Based to the different types of electrolyte, working temperatures and fuels employed, different types of fuel cell exist. For our purpose, a PEMFC (Polymeric Exchange Membrane Fuel Cell), whose schematic is presented in fig. 1 is used. It is characterized by:

- $\quad$ Low working temperatures;

- High efficiency;

- Low requirement of maintenance;

- Auto-humidification of membrane;

- High ratio power/dimensions. 


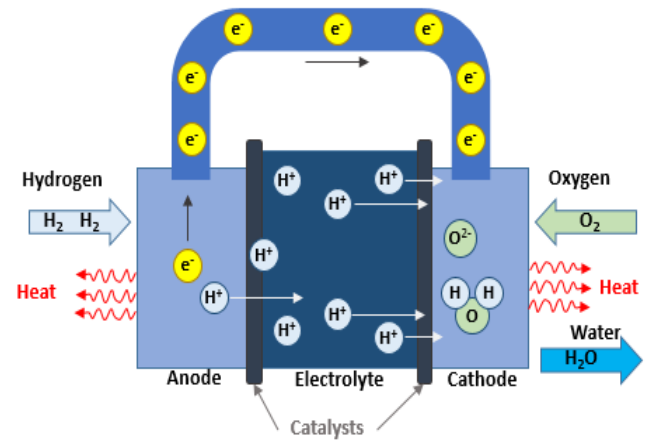

Fig.1 Schematic of a PEMFC [32]

In the PEMFC, hydrogen is used as a fuel and oxygen taken from the air as combustive. The electrolyte employed is a solid polymeric membrane made by Nafion 177 . It allows a perfect separation between the elements reacted at the electrodes, as shown in the following equations:

$$
\begin{gathered}
2 \mathrm{H}_{2} \rightarrow 4 \mathrm{H}^{+}+4 \mathrm{e}^{-} \\
\mathrm{O}_{2}+4 \mathrm{e}^{-}+4 \mathrm{H}^{+} \rightarrow 2 \mathrm{H}_{2} \mathrm{O}
\end{gathered}
$$

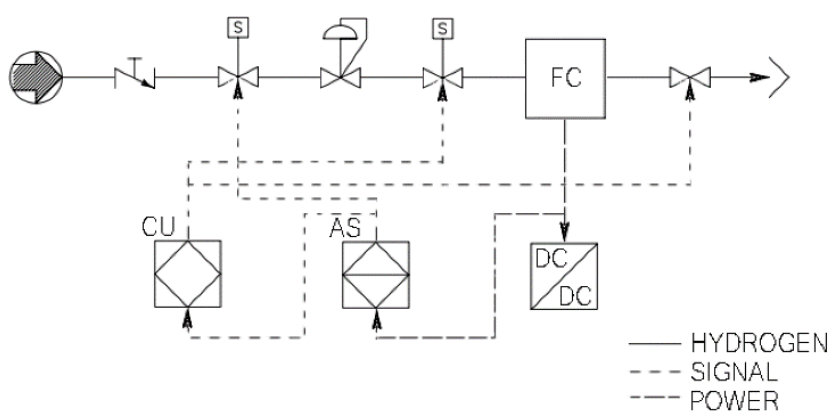

Fig 2 Schematic circuit of the hydrogen-based supply system.

\section{B. Design of the hydrogen based supply system}

The devices employed for the realization of the hydrogen-based supply system whose scheme is shown in fig. 2 are described below.

- $\quad 300 \mathrm{~W}$ PEMFC (FC), 69V maximum voltage;

- Purge valve;

- Inlet valve;

- Solenoid electro valve to avoid hydrogen peaks;

- $\quad$ Pressure regulator to avoid high pressure at the entry of the fuel cell;

- Alarm system (AS) composed by: hydrogen sensor, high temperature sensor, high voltage sensor;

- $\quad$ Control unit (CU);

- DC-DC converter.

The hydrogen is stocked thanks to a hydride metal storage. With difference to the conventional hydrogen storage systems, the hydride metal technology can allow the stockpile of 900 litres of hydrogen at the pressure of $10 \mathrm{bar}$ in a $5 \mathrm{~kg}$ compact tank [33]. The assembled supply system is shown in fig. 3.

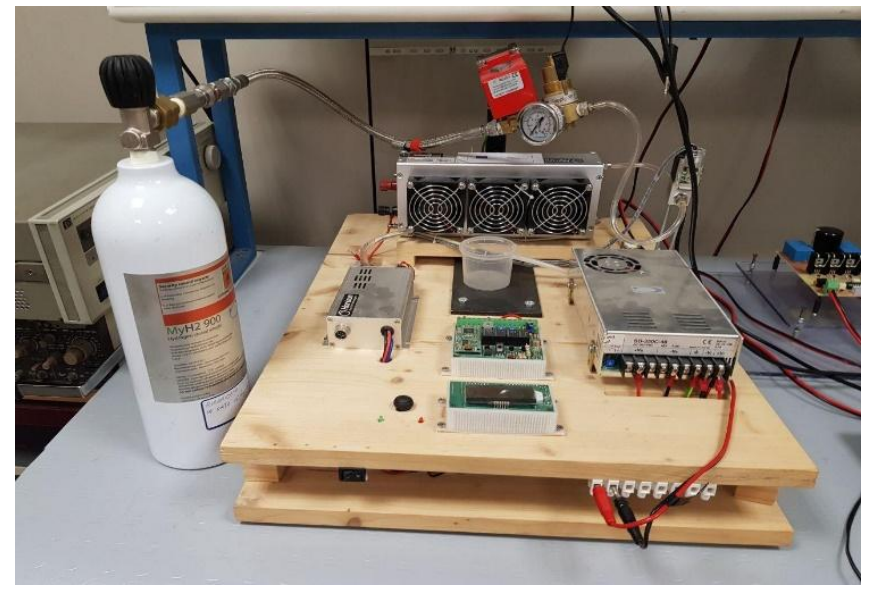

Fig.3 Hydrogen based supply system

\section{IPT SYSTEM}

The proposed IPT system was designed and realized entirely in laboratory. In this paragraph, the proposed system is described.

\section{A. Inductive Power Transfer System Description}

Fig 4. Shows the circuit schematic of the proposed wireless charging system, consisting of the two coupled inductors and two symmetrical sides, referenced as primary

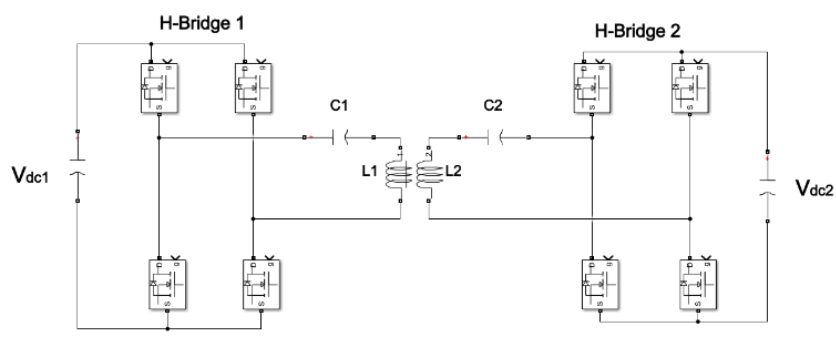

Fig.4 Schematic of an IPT based on SS compensation

and secondary side. Each side consists of a DC source, a Hbridge converter and a capacitor. The IPT system is based on the magnetic coupling between the two coils. The capacitors are used for the reactive power compensation and along with the self-inductances, determine the system resonant frequency. This proposed system is based on a Series-Series compensation, which provides advantages in terms of power regulation facility, as a matter of fact, the resonant frequency depends only on the self-inductance [33].

The primary H-bridge converter provides to the alternate voltage having frequency equal to the resonance one. The secondary side converter is used as a rectifier in order to supply the load.

\section{B. Design and Realization of the IPT system}

The H-bridge converters were studied in simulation, designed and realized in laboratory, using the IRFB4410Z power N-Channel MOSFETs for high frequency [34]. The N-Channel MOSFETs are driven by the HIP4081A [35]. For a proper operation of the driver, an external bootstrap circuit with capacitors and diodes are needed. The inductors employed for the system are circular planar coils with 13 
$\mu \mathrm{H}$ auto-inductance, the series compensation circuit is composed by a PET capacitors bench equal to $250 \mathrm{nF}$. For this reason, the resonance frequency is equal to $94,1 \mathrm{kHz}$. The control of the system is given to the shield Arduino DUE. In fig. 5 the structure of the coils is shown.

\section{EXPERIMENTAL TESTS}

In order to evaluate the proposed system, simulations in Matlab/Simulink and experimental tests have been carried out, concerning a power transfer from the primary to the secondary side.
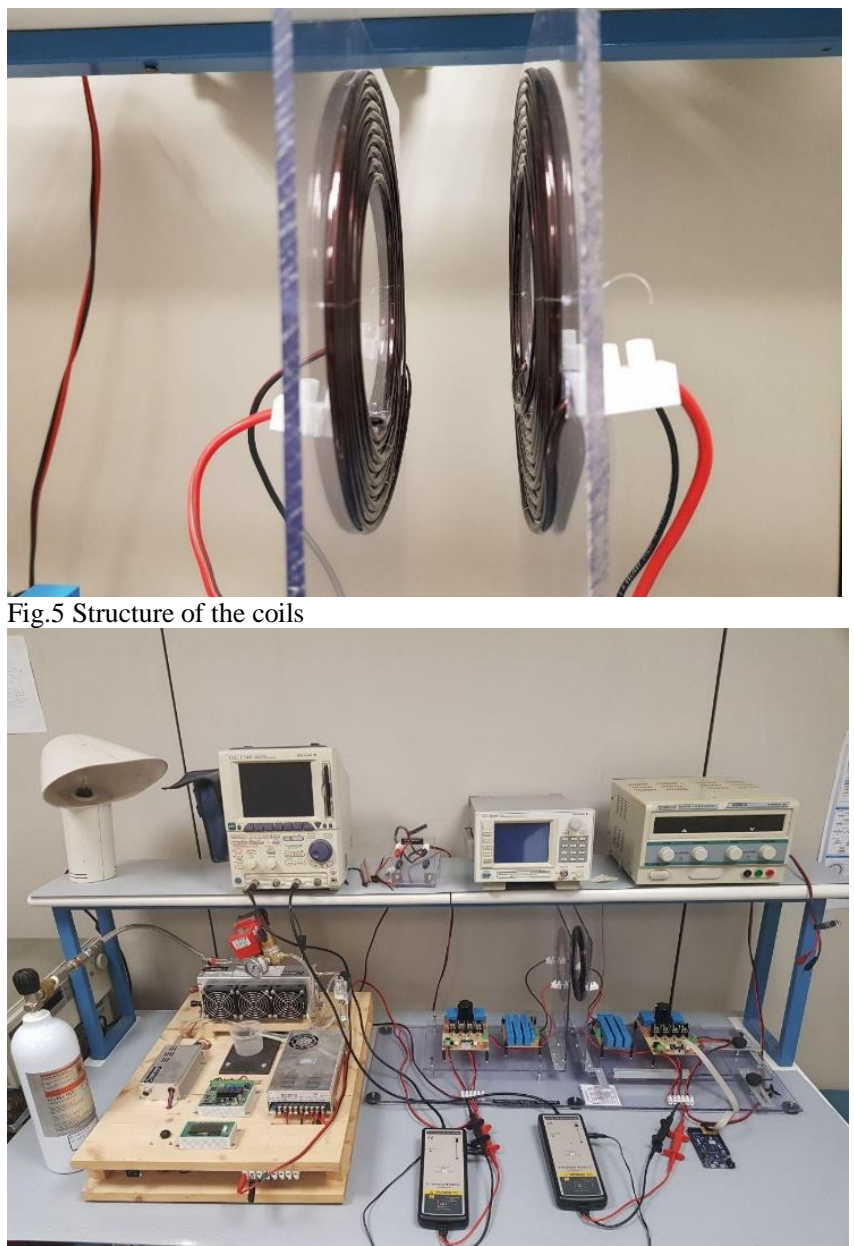

Fig. 6 Assembled system

In fig. 6 the test bench is shown. It is composed by the hydrogen-based supply described in paragraph II, the IPT system described in paragraph III, an oscilloscope Yokogawa DL 1790, two differential voltage scopes, two current scopes and an electronic load.

The goal of the tests is the efficiency characterization of the IPT system when supplied by a fuel cell, in order to verify the employment possibility of such kind of apparats in no electrified areas. Wireless power transmission strongly depends on the distance between the two coils and on the misalignment. For this reason, the tests are carried out with distances variable between the two inductors from $1 \mathrm{~cm}$ to 4 $\mathrm{cm}$ with steps equal to $0,5 \mathrm{~cm}$ and misalignment from 0 to 4 $\mathrm{cm}$ with steps equal to $0,5 \mathrm{~cm}$ in different load conditions set on an electronic load, from $1 \Omega$ to $20 \Omega$ with steps equal to $1 \Omega$. The output voltage of the supply system is equal to
$24 \mathrm{~V}$ given by a DC-DC interposed between the supply system and the IPT system.

The DC-DC converter has also a second important scope. In order to have an auto-humidification of the membrane of the fuel cell, a short circuit unit is installed. It allows to the short-circuit of the cells for $200 \mathrm{~ms}$ every $10 \mathrm{~s}$. For this reason, the DC-DC converter allows to a more stabilized input voltage. In fig. 7 and 8 (CH1) the not stabilized voltage trend and the stabilized one are shown.

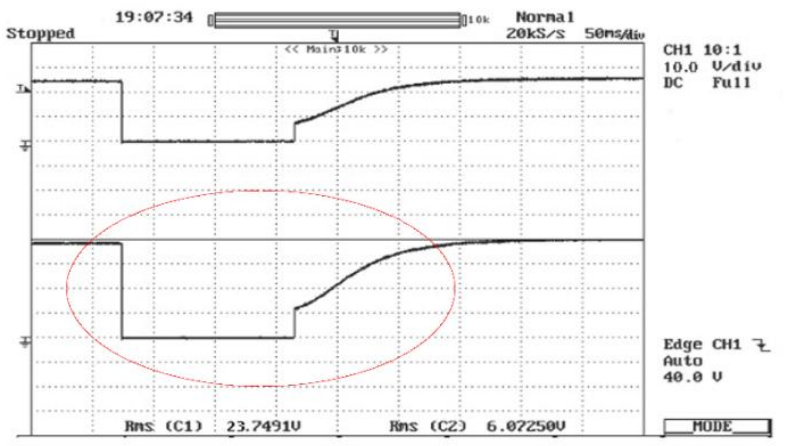

Fig.7 Not stabilized voltage trend

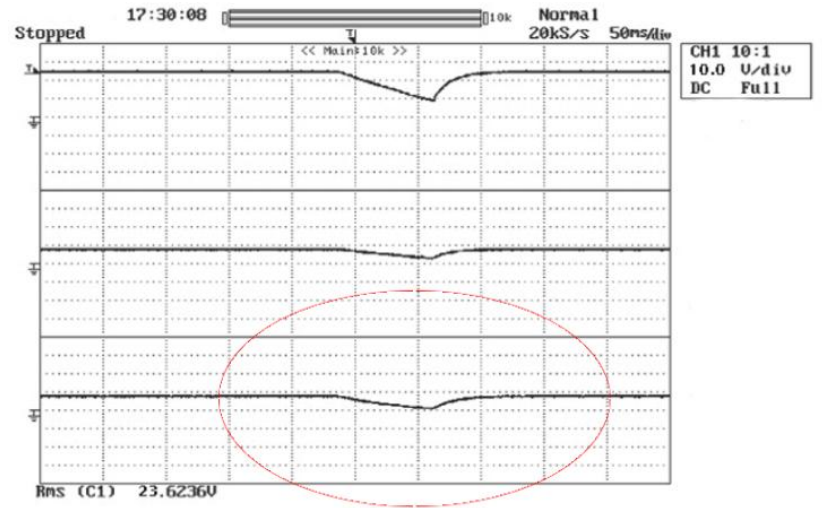

Fig.8 Stabilized voltage trend

The input and the output voltage and current of the system were measured, and the input and output power calculated, therefore the efficiency for each value of load, distance and misalignment.

\section{EXPERIMENTAL RESULTS}

Tests carried out show how the hydrogen-based supply system presents a suitable response to the load current requirements. The maximum efficiency is equal to $76,3 \%$ and it is obtained for a load value equal to $10 \Omega$ with a distance equal to $1 \mathrm{~cm}$ and no misalignment. In the next figures, the efficiency is shown in dependence to the distance and the misalignment for two different load conditions. It is important to notice how efficiency decreases in general with the increase of distances and misalignment. Besides, with a load value equal to $2 \Omega$, even though the maximum efficiency value is low, equal to $64,7 \%$, its dependence with distance and misalignment is not significant if compared to the case of $10 \Omega$ load, for which the system reaches its maximum value. As a matter of fact, the in the distance range from $1 \mathrm{~cm}$ to $4 \mathrm{~cm}$, for the $2 \Omega$ load, the maximum efficiency variation is equal to $7,2 \%$ 
while for the $10 \Omega$ load, it is equal to $24,3 \%$. As for the misalignment range from $0 \mathrm{~cm}$ to $4 \mathrm{~cm}$, the maximum efficiency variation for the $2 \Omega$ load is equal to $2,1 \%$, while for the $10 \Omega$ load, it is equal to $23,3 \%$. It is a significant result that shows how, external factors such as misalignment and distance cannot be neglected and that a correct load matching is required in the design stage of the system.

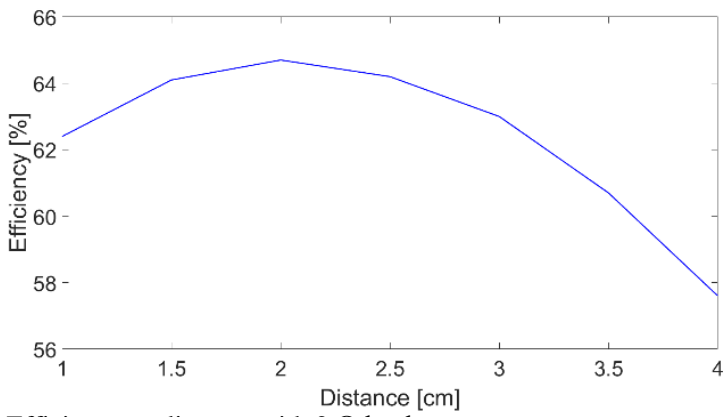

Fig. 9. Efficiency vs distance with $2 \Omega$ load.

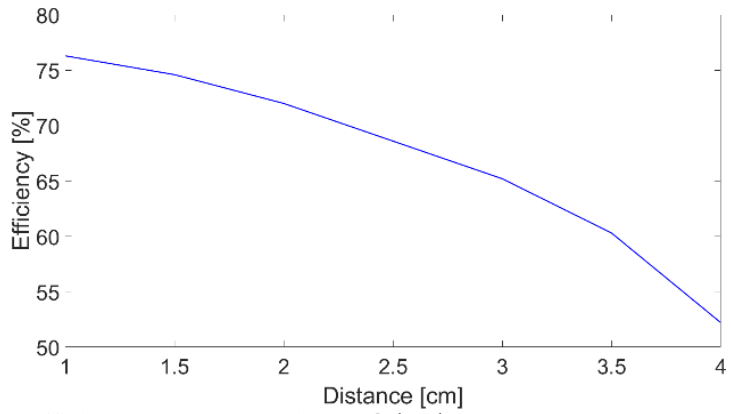

Fig. 10. Efficiency vs distance with $10 \Omega$ load.

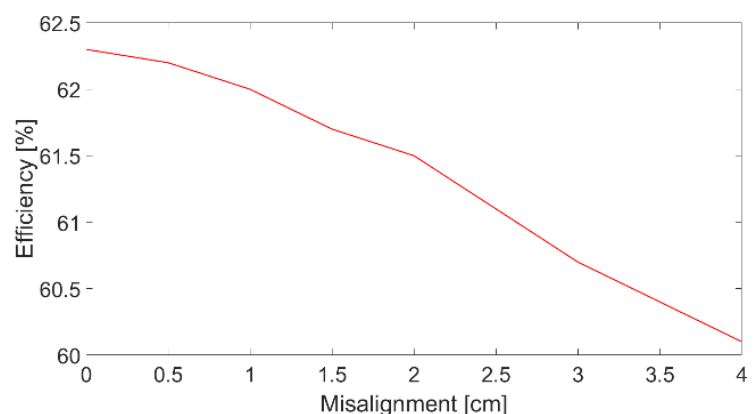

Fig. 11. Efficiency vs misalignment with $2 \Omega$ load

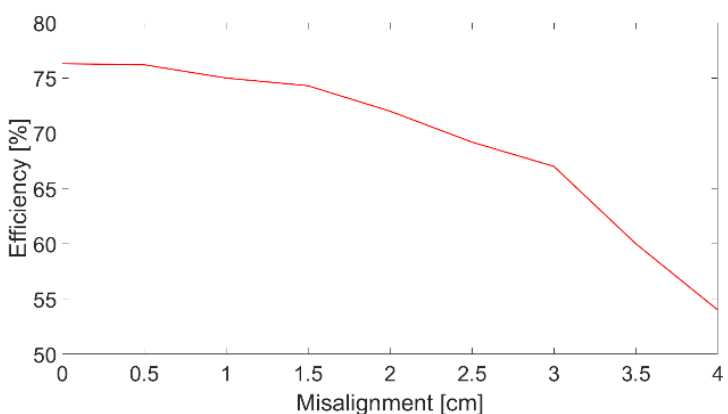

Fig. 12. Efficiency vs misalignment with $10 \Omega$ load

\section{CONCLUSIONS}

In this paper, a low power prototype of a hydrogen supplied Wireless Charging System is presented and characterized. The IPT system represents an innovative solution in terms of safety and comfort, the hydrogen-based supply system allows the installation of the whole system in not electrified areas. The hydrogen refill can be obtained thanks to an electrolyser supplied by a low power photovoltaic panel, cheaper than a traditional photovoltaic plant paired with a traditional battery. The hydrogen-based system was chosen and customized to the IPT system requirements. The experimental tests confirmed the possibility of employment of this kind of technology as a valid solution for grid-disconnected systems. An efficiency analysis of the IPT system was carried out showing how wireless charging system is a valid and concrete solution for the EVs charging, presenting high values of efficiency, even though a correct load matching is needed because external factors such as distance between coils and misalignment cannot be neglected inasmuch they affect efficiency.

\section{ACKNOWLEDGMENT}

This work was financially supported by PON R\&I 20152020 "Propulsione e Sistemi Ibridi per velivoli ad ala fissa e rotante - PROSIB", CUP no:B66C18000290005, by H2020ECSEL-2017-1-IA-two-stage "first and european sic eightinches pilot line-REACTION", by Prin 2017- Settore/Ambito di intervento: PE7 linea $\mathrm{C}$ - Advanced power-trains and -systems for full electric aircrafts, by PON R\&I 2014-2020 - AIM (Attraction and International Mobility), project AIM1851228-1 and by ARS01_00459-PRJ-0052 ADAS+ "Sviluppo di tecnologie e sistemi avanzati per la sicurezza dell'auto mediante piattaforme ADAS".

\section{REFERENCES}

[1] Z. Zhang, H. Pang, A. Georgiadis and C. Cecati, "Wireless Power Transfer-An Overview," in IEEE Transactions on Industrial Electronics, vol. 66, no. 2, pp. 1044-1058, Feb. 2019.

[2] C. T. Rim and C. Mi, Wireless Power Transfer for Electric Vehicles and Mobile Devices. Hoboken, NJ, USA: Wiley-IEEE Press, 2017.

[3] W.X.ZhongandS.Y.R.Hui,"Maximumenergyefficiencytrackingfor wireless power transfer systems," IEEE Trans. Power Electron., vol. 30, no. 7, pp. 4025-4034, Jul. 2015.

[4] W. Zhang, S.-C. Wong, C. K. Tse, and Q. Chen, "Analysis and comparison of secondary series- and parallel-compensated inductive power transfer systems operating for optimal efficiency and loadindependent voltage-transfer ratio," IEEE Trans. Power Electron., vol. 29, no. 6, pp. 2979-2990, Jun. 2014

[5] H. C. Li, J. Li, K. P. Wang, W. J. Chen, and X. Yang, "A maximum efficiency point tracking control scheme for wireless power transfer systems using magnetic resonant coupling," IEEE Trans. Power Electron., vol. 30, no. 7, pp. 3998-4008, Jul. 2015.

[6] Cecconi, V., Di Dio, V., Di Tommaso, A.O., Di Tommaso, S., La Cascia, D., Miceli, R. Active power maximizing for wind electrical energy generating systems moved by a modular multiple blade fixed pitch wind turbine (2008) SPEEDAM 2008 - International Symposium on Power Electronics, Electrical Drives, Automation and Motion, art. no. 4581301, pp. 1460-1465.

[7] Pellitteri, F., Ala, G., Caruso, M., Ganci, S., Miceli, R. Physiological compatibility of wireless chargers for electric bicycles (2015) 2015 International Conference on Renewable Energy Research and Applications, ICRERA 2015, art. no. 7418629, pp. 1354-1359.

[8] Di Tommaso, A.O., Miceli, R., Galluzzo, G.R., Trapanese, M. Efficiency maximization of permanent magnet synchronous generators coupled to wind turbines (2007) PESC Record - IEEE Annual Power Electronics Specialists Conference, art. no. 4342175.

[9] Acciari, G., Caruso, M., Miceli, R., Riggi, L., Romano, P., Schettino, G., Viola, F. Piezoelectric Rainfall Energy Harvester Performance by an Advanced Arduino-Based Measuring System (2018) IEEE Transactions on Industry Applications, 54 (1), art. no. 8036268 
[10] Caruso, M., Cecconi, V., Di Tommaso, A.O., Rocha, R. Sensorless variable speed single-phase induction motor drive system based on direct rotor flux orientation (2012) Proceedings - 2012 20th International Conference on Electrical Machines, ICEM 2012, art. no. 6350007.

[11] Caruso, M., Di Tommaso, A.O., Imburgia, A., Longo, M., Miceli, R., Romano, P., Salvo, G., Schettino, G., Spataro, C., Viola, F. Economic evaluation of $\mathrm{PV}$ system for $\mathrm{EV}$ charging stations: Comparison between matching maximum orientation and storage system employment (2017) 2016 IEEE International Conference on Renewable Energy Research and Applications, ICRERA 2016, art. no. 7884519, pp. 1179-1184.

[12] Schettino, G., Buccella, C., Caruso, M., Cecati, C., Castiglia, V., Miceli, R., Viola, F. Overview and experimental analysis of MC SPWM techniques for single-phase five level cascaded H-bridge FPGA controller-based (2016) IECON Proceedings (Industrial Electronics Conference), art. no. 7793351, pp. 4529-4534.

[13] Caruso, M., Cecconi, V., Di Tommaso, A.O., Rocha, R. Sensorless variable speed single-phase induction motor drive system (2012) 2012 IEEE International Conference on Industrial Technology, ICIT 2012, Proceedings, art. no. 6210025, pp. 731-736.

[14] Caruso, M., Di Tommaso, A.O., Miceli, R., Ognibene, P., Galluzzo, G.R. An IPMSM torque/weight and torque/moment of inertia ratio optimization (2014) 2014 International Symposium on Power Electronics, Electrical Drives, Automation and Motion, SPEEDAM 2014, art. no. 6871997, pp. 31-36.

[15] Caruso, M., Di Tommaso, A.O., Miceli, R., Galluzzo, G.R., Romano, P., Schettino, G., Viola, F. Design and experimental characterization of a low-cost, real-time, wireless AC monitoring system based on ATmega 328P-PU microcontroller (2015) 2015 AEIT International Annual Conference, AEIT 2015, art. no. 7415267.

[16] Caruso, M., Cipriani, G., Di Dio, V., Miceli, R., Nevoloso, C. Experimental characterization and comparison of TLIM performances with different primary winding connections (2017) Electric Power Systems Research, 146, pp. 198-205.

[17] Imburgia, A., Romano, P., Caruso, M., Viola, F., Miceli, R., Riva Sanseverino, E., Madonia, A., Schettino, G. Contributed Review: Review of thermal methods for space charge measurement (2016) Review of Scientific Instruments, 87 (11), art. no. 111501.

[18] Livreri, P., Caruso, M., Castiglia, V., Pellitteri, F., Schettino, G.Dynamic reconfiguration of electrical connections for partially shaded PV modules: Technical and economical performances of an Arduino-based prototype(2018) International Journal of Renewable Energy Research, 8 (1), pp. 336-344.

[19] Busacca et al, R. Parametrical study of multilayer structures for CIGS solar cells (2014) 3rd International Conference on Renewable Energy Research and Applications, ICRERA 2014, art. no. 7016528.

[20] Di Dio, V., Favuzza, S., La Caseia, D., Miceli, R. Economical incentives and systems of certification for the production of electrical energy from renewable energy resources (2007) 2007 Internationa Conference on Clean Electrical Power, ICCEP '07, art. no. 4272394.

[21] Viola, F., Romano, P., Miceli, R., Spataro, C., Schettino, G. Technical and economical evaluation on the use of reconfiguration systems in some EU countries for PV plants (2017) IEEE
Transactions on Industry Applications, 53 (2), art. no. 7736973, pp. 1308-1315.

[22] Viola, F., Romano, P., Miceli, R., Spataro, C., Schettino, G.Survey on power increase of power by employment of PV reconfigurator(2015) 2015 International Conference on Renewable Energy Research and Applications, ICRERA 2015, art. no. 7418689, pp. 1665-1668.

[23] F. Pellitteri, N. Campagna, V. Castiglia, A. Damiano and R. Miceli, "Design, implementation and experimental results of a wireless charger for E-bikes," 2019 International Conference on Clean Electrical Power (ICCEP), Otranto, Italy, 2019, pp. 364-369.

[24] G. Vacheva and N. Hinov, "An Overview of the State of Art of Fuel Cells in Electric Vehicles," 2019 International Conference on Creative Business for Smart and Sustainable Growth (CREBUS), Sandanski, Bulgaria, 2019, pp. 1-4.

[25] J. P. Gagge, "PEM fuel cells versus diesel generators — which solution to pick?," INTELEC 2008 - 2008 IEEE 30th International Telecommunications Energy Conference, San Diego, CA, 2008.

[26] Siou-Cheng Li, Cheng-Yung Gao and F. Wang, "Control and development of a PEMFC electric bicycle," 2014 Proceedings of the SICE Annual Conference (SICE), Sapporo, 2014, pp. 1017-1022.

[27] J. Weigl, I. Inayati, E. Zind and H. Said, "Pios fuel cell Motorcycle; design, development and test of hydrogen fuel cell powered vehicle," 2008 IEEE International Conference on Sustainable Energy Technologies, Singapore, 2008, pp. 1120-1122.

[28] S. V. M. Guaitolini, I. Yahyaoui, J. F. Fardin, L. F. Encarnação and F. Tadeo, "A review of fuel cell and energy cogeneration technologies," 2018 9th International Renewable Energy Congress (IREC), Hammamet, 2018, pp. 1-6.

[29] M. Sharma, R. K. Pachauri and S. K. Goel, "MATLAB/Simulink modeling and analysis of parametric effects on PEMFC performance," 2015 International Conference on Recent Developments in Control, Automation and Power Engineering (RDCAPE), Noida, 2015, pp. 226-231.

[30] Z. B. A. Mat, Madya, Y. B. Kar, S. H. B. A. Hassan and N. A. B. Talik, "Proton exchange membrane (PEM) and solid oxide (SOFC) fuel cell based vehicles-a review," 2017 2nd IEEE International Conference on Intelligent Transportation Engineering (ICITE), Singapore, 2017, pp. 123-126.

[31] https://www.h2sys.fr/en/technologies-2/fuel-cell-systems/

[32] N. Campagna, A. O. Di Tommaso, F. Genduso, R. Miceli, F. M. Raimondi and G. R. Galluzzo, "Experimental characterization of a proton exchange membrane fuel-cell for hybrid electric pedal assisted cycles," 2017 IEEE 6th International Conference on Renewable Energy Research and Applications (ICRERA), San Diego, CA, 2017, pp. 1210-1214.

[33] N. Campagna, V. Castiglia, R. Miceli and F. Pellitteri, "A Bidirectional IPT system for Electrical Bicycle Contactless Energy Transfer," 2019 8th International Conference on Renewable Energy Research and Applications (ICRERA), Brasov, Romania.

[34] MOSFET technical datasheet - [Online]. Available: https://www.infineon.com/dgdl/irfb4410zpbf.pdf?fileId=5546d46253 3600a40153561644141e3a.

[35] MOSFET Driver technical datasheet - [Online]. Available: https://www.renesas.com/eu/en/www/doc/datasheet/hip4081a. 